RESEARCH PAPER RP1165

Part of Journal of Research of the National Bureau of Standards, Volume 22, January 1939

\title{
SOLUBILITY OF LEAD SULFATE IN SOLUTIONS OF SULFURIC ACID, DETERMINED BY DITHIZONE WITH A PHOTRONIC CELL
}

\author{
By D. Norman Craig and George W. Vinal
}

\section{ABSTRACT}

New determinations of the solubility of lead sulfate in sulfuric acid solutions have been made, using diphenylthiocarbazone, commonly called dithizone, as the reagent. This provides a very sensitive method for small quantities of lead. The equivalence point was detected by a simple arrangement of a photronic cell and color filter. The range of concentrations of acid extended from 0.1 to 50 percent $\mathrm{H}_{2} \mathrm{SO}_{4}$. Determinations of the lead could be made with an average error not exceeding 0.7 microgram $(\mu \mathrm{g})$. Determinations were made at $25^{\circ}$ and $0^{\circ} \mathrm{C}$, employing solutions, some of which were brought to saturation equilibrium from undersaturation and others from supersaturation. Important maxima and minima in the solubility curves which had not been reported previously were found. Tables are given for the solubility of the salt at $25^{\circ}$ and $0^{\circ} \mathrm{C}$. Comparison is made of the effect of $\mathrm{H}_{2} \mathrm{SO}_{4}$ on the solubility of lead and mercurous sulfates. The trend of the curves for these is strikingly similar, although the latter is more than 80 times as soluble.

\section{CONTENTS}

I. Introduction

II. Experimental procedure

1. Materials

2. Saturation of solutions

3. Description of the method

4. Details of the determinations

5. Test of the method. 60

6. Determination of sulfuric acid

III. Experimental results

IV. Solubility of lead sulfate at regular intervals of sulfuric acid concentration_ 65

V. Discussion of results

VI. Comparison with the results of others

VII. References

\section{INTRODUCTION}

Lead sulfate, which plays an important part in chemical reactions of the lead storage battery, is formed in accordance with Faraday's law during discharge. Considerable amounts may exist in the active material of the plates, but the amounts which are dissolved in the sulfuric acid electrolyte are extremely small under equilibrium conditions. Only a few previous papers have reported solubility measurements of lead sulfate in sulfuric acid solutions of concentrations comparable with those used in batteries. It seemed desirable, therefore, that some further investigation should be made of this subject, especially as sensitive determinations can now be made by methods not previously used in this problem. 
In 1929 Fischer [1] ${ }^{1}$ introduced a sensitive reagent for small quantities of lead which has found interesting applications in widely diverse fields. Diphenylthiocarbazone, or dithizone as it is commonly called, has the formula

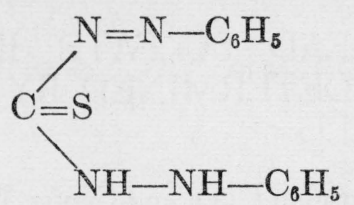

according to Fischer [2]. We have made no study of this reagent, except to find means of using it in our problem of measuring the solubility of lead sulfate.

Dissolved in chloroform, dithizone imparts a noticeable green tint to the solution, provided the solution is not too concentrated. The lead-dithizone complex, however, has a bright cherry-red color. Spectrophotometric studies of these solutions have been reported previously in the technical literature. A discussion of the spectral transmission and its applications to the quantitative determination of lead may be found in a paper by Clifford and Wichmann [3].

In some of our earlier experiments, spectrophotometric measurements of a few solutions were made with the cooperation of members of the Spectrophotometry Section. As a result of these experiments we have developed a simpler and quicker method, employing a photronic cell with light source and color filter as a means cf detecting the equivalence point. This method was tested many times by making determinations on solutions to which one observer added known amounts of lead, while the determinations were made by another observer who did not know these amounts until the experiments were completed. The accuracy attained was considered ample for the purpose and we feel confident that this method, which involves the use of simple and readily obtainable apparatus, fulfilled our needs.

Dithizone is known to react with metals other than lead. The precautions taken to avoid interference by other metals are discussed on page 58. These precautions, together with the spectroscopic analysis of the lead salt and the redistillation of water and acid, make it highly improbable that the results were affected by other metals. Confirmation of this is found in the analysis of solutions of known lead content.

Comparisons of the results of our measurements with those of others who employed different methods for the determination of lead are given in a later section of this paper.

The range of acid concentrations covered by the present work is from 0.08 to 50 percent. Some of the solutions were brought to saturation equilibrium with respect to lead sulfate from an undersaturated state and others from a supersaturated state. Determinations were made at two temperatures, $25^{\circ}$ and $0^{\circ} \mathrm{C}$.

In the course of the work a well-defined maximum of solubility was found for solutions of approximately 10 percent or molar concentration of acid. This is similar to the solubility of mercurous sulfate in sulfuric acid solutions. Although the mercurous sulfate is more than 80 times as soluble as the lead sulfate in solutions of corresponding

1 Numbers in brackets indicate the literature references given at the end of this paper. 
strength, the similarity of curves for lead and mercurous sulfates is remarkable. The ratio of the two salts holds constant when the molarity of the acid concentrations varies from 0.0025 to 2.5 molar. This is discussed in the paper, and reference is made to the solubility data for calcium and silver sulfates as found in the technical literature.

\section{EXPERIMENTAL PROCEDURE}

\section{MATERIALS}

The lead sulfate was part of a sample prepared from lead nitrate which had been twice recrystallized. In converting the lead nitrate to lead sulfate, redistilled sulfuric acid was used. It was added slowly to the hot lead nitrate solution which was stirred continuously. The lead sulfate was repeatedly digested on the steam bath in solutions of redistilled sulfuric acid. A sample of the final product was tested spectroscopically for the presence of impurities by the Spectroscopy Section of this Bureau. Only faint traces of iron and magnesium were reported.

The sulfuric acid conformed to the requirements recommended by a committee of the American Chemical Society for reagent grade acid [4]. As a further precaution this was distilled and the middle fractions only used in this work.

The water was all redistilled. At the time it was made its conductivity was $1 \times 10^{-7}$ or below. This was considerably better, therefore, than ordinary distilled water. It was prepared from time to time as required.

The principal reagent used in this work was diphenylthiocarbazone commonly called by the shorter name, "dithizone." It was obtained from the Eastman Kodak Co. All other reagents including nitric acid, ammonium hydroxide, potassium cyanide, and chloroform were of reagent grade and these were used in exactly the same quantities in the known and unknown solutions during the analysis.

The standard lead solution was prepared from high-grade lead as a nitrate solution, containing $100 \mu \mathrm{g}$ of lead per milliliter of solution.

\section{SATURATION OF SOLUTIONS}

The saturation of the solutions was accomplished by agitating them mechanically with Pyrex-glass stirrers in 500-ml Pyrex flasks, containing a liberal excess of lead sulfate. At $25^{\circ} \mathrm{C}$ the temperature was controlled thermostatically to $\pm 0.02^{\circ} \mathrm{C}$ in a water bath. At $0^{\circ} \mathrm{C}$ the temperature was controlled by a mixture of ice and water in large Dewar flasks. The experimental results at both temperatures include values obtained by approaching the saturation equilibrium from a condition of incomplete saturation and from supersaturation. For the latter, solutions previously saturated at a higher temperature were employed.

After agitating the solutions for 3 days at $25^{\circ} \mathrm{C}$ and 6 days at $0^{\circ} \mathrm{C}$, the stirrers were removed and the flasks were allowed to stand at their respective temperatures 10 to 24 hours before removing the samples. The samples of the supernatant solutions were carefully removed by suction through fritted-glass filters. Five samples of $25 \mathrm{ml}$ were drawn from each flask and the first four samples were discarded. Analysis was made of the fifth sample which was placed in a silica 
dish for evaporation to dryness. After each time the funnels were used they were cleaned by passing $6 N \mathrm{HNO}_{3}$ through them in the reverse direction and this was followed by repeated washings with distilled water. They were kept in closed vessels when not in use.

\section{DESCRIPTION OF THE METHOD}

The usefulness of dithizone for determining small quantities of lead depends upon the reaction of lead with dithizone, which is accompanied by a change in color from the original green of dithizone in chloroform to the cherry red of the lead-dithizone complex. The reaction is conveniently carried out in a two-phase liquid system, one phase being an aqueous solution of fixed $\mathrm{pH}$, greater than 7 , and the second phase an organic liquid immiscible with water, such as chloroform or carbon tetrachloride, which readily dissolves the lead-dithizone complex. Free dithizone is soluble also in aqueous ammonia solutions, producing a yellow color. The distribution of dithizone between chloroform and ammonia solutions depends upon the $\mathrm{pH}$ of the aqueous phase. The distribution of lead in the two phases is dependent not only on the $\mathrm{pH}$ of the aqueous phase, but also on the concentration of the dithizone.

Dithizone is known to react with many metal ions forming various colored complexes, each of which has its own characteristic color. Several authors [5] have reported that the number of metals whose ions react with the dithizone may be greatly reduced by the addition of potassium cyanide to the aqueous solution. As a precaution, which may not have been necessary, we used potassium cyanide in analyzing all of our solutions. There still remain thallium, bismuth, and stannous tin which may interfere notwithstanding the presence of potassium cyanide. However, any errors which might have been caused by these were doubtless inappreciable, because the report of spectroscopic test of the lead sulfate stated specifically that the spectrum was examined for sensitive lines of these and about 50 other elements, but only faint traces of iron and magnesium were found. Dithizone is not sensitive to magnesium and the amount of iron present was too small to be significant. This conclusion is further justified by analyses of known solutions reported later in this paper. We believe, therefore, the analyses were not affected by interfering elements. It is not the purpose of this paper to discuss equilibria involved in the use of dithizone, but rather to report the use of dithizone for determining small amounts of lead with relatively simple apparatus.

The procedure which we have followed was the result of preliminary experiments which showed that known amounts of lead could be accurately measured. The apparatus consisted of a light source (21 cp 12-16 v lamp with collimator), a red filter of selenium glass, a photronic cell, and a sensitive microammeter for measuring the electric current delivered by the photronic cell. Current for the lamp was supplied by a storage battery through soldered connections. Errors which might have arisen from drift in the intensity of the light source or in the response of the photronic cell were avoided by the procedure outlined on page 61 . This arrangement affords a very sensitive method of correlating color changes of the solutions with the lead content. 


\section{DETAILS OF THE DETERMINATIONS}

The 25-ml portions of sulfuric acid solutions saturated with lead sulfate were evaporated to dryness in silica dishes on an air bath over a carefully regulated bunsen flame. Care was taken to avoid contamination of the samples at all times. After evaporation had been completed $0.4 \mathrm{ml}$ of concentrated $\mathrm{HNO}_{3}$ were added to the lead sulfate residue in the silica dish. The dish was then slowly tipped and rotated until the acid wet all parts of the inner surface. Ten ml of water were then added and the process repeated while the surface was rubbed with a policeman which was reserved for this purpose. The solution was then transferred to a Pyrex separatory funnel, cleaned immediately before use, and reserved for this purpose. ${ }^{2}$

The process of rinsing the silica dish was then repeated twice, using $0.3 \mathrm{ml}$ of concentrated acid and $10 \mathrm{ml}$ of water. After rubbing all parts of the inner surface of the silica dish with the policeman, both rinsings were in turn added to the solution in the separatory funnel. Three successive portions of water, $2 \mathrm{ml}$ each, were added to the dish and the policeman used as before. Each of these solutions in turn was transferred to the Pyrex separatory funnel. The separatory funnel then contained the lead sulfate residue in $36 \mathrm{ml}$ of water and $1 \mathrm{ml}$ of $\mathrm{HNO}_{3}$.

Thirty-six $\mathrm{ml}$ of water and $1 \mathrm{ml}$ of concentrated $\mathrm{HNO}_{3}$ were then placed in a second separatory funnel using the same pipettes as in the previous case. To each of the solutions in the separatory funnels $3 \mathrm{ml}$ of concentrated $\mathrm{NH}_{4} \mathrm{OH}$ followed by $0.5 \mathrm{ml}$ of $\mathrm{KCN}$ solution $\left(10 \mathrm{~g}\right.$ in $\left.50 \mathrm{ml} \mathrm{H} \mathrm{H}_{2} \mathrm{O}\right)$ were added. The two solutions in their respective separatory funnels were at this point identical in volume and composition except for the amount of lead sulfate in the first separatory funnel. This solution will hereafter be designated as the unknown solution. The other solution to which a measured amount of lead was to be added will be designated as the known solution.

Measured portions of a solution of dithizone in chloroform were added to the unknown solution. The addition of each portion was followed by shaking, and this process was repeated until the additions of the dithizone were sufficient to cause a visual change in color of the chloroform solution from cherry red to a purplish red, which indicated that a slight excess of dithizone had been added. The concentration of dithizone in the chloroform being known, an approximate calculation of the lead in the unknown solution could be made. A volume of standard lead nitrate solution containing nearly an equivalent amount of lead was added immediately to the known solution in the other separa tory funnel, using a 1-ml pipette graduated to hundredths. The same number of equal portions of dithizone in chloroform were then added to the known solution. After each portion was added, the solution was shaken. At this point the two solutions contain exactly the same amount of dithizone, chloroform, approximately the same amount of lead, and both should have a purplish-red color.

The colored chloroform solution was then delivered into a cylindri-

\footnotetext{
2 The process of cleaning the separatory funnels is important. Each was partially filled with dilute ammonia and a chloroform solution of dithizone. The funnels were then shaken repeatedly and examined between each shaking for change in color of the dithizone. If this experiment is tried on soft glass containing lead the effect of the lead in the glass mav be detected. When the Pyrex funnels were satisfactorily cleaned they were drained and used without further rinsing.
} 
cal glass cell with flat bottom. This was placed over the photronic cell and the reading of the microammeter recorded for comparison with readings of the meter immediately before and after. The ratio of the reading when the cell was present to the mean of the two readings without the cell was then calculated. The chloroform solution was then returned to the separatory funnel. The same process was repeated with the other chloroform solution using the same glass cell. It was evident from the readings of the meter which solution contained less lead. To this solution a small portion of the standard lead nitrate solution was added. Both separatory funnels were shaken simultaneously and measurements with the photronic cell repeated. This process was continued until there was definitely more lead in this solution than in the other solution. The observations were correlated with the amounts of lead and the equivalence points with respect to lead determined graphically.

\section{TEST OF THE METHOD}

The following examples serve a double purpose in illustrating the method and in showing the accuracy which may be attained in analyzing solutions which are designated as "test solutions." Actually, the amounts of lead in the test solutions were known to one of us, but the analyses were made by the other who did not know the amounts until after the experiments were completed.

The tests of the method were first made on solutions of lead nitrate, which did not require evaporation of the solutions. An example is given in detail below. Other tests were made on sulfuric acid solutions to which lead was added as lead nitrate. These were evaporated in silica vessels exactly as was done in the case of the unknown solutions which were saturated with lead sulfate. Tests of the method were made repeatedly, but three experiments are sufficient to illustrate (1) the method of making the determinations and (2) the reliability of determinations of lead initially present in sulfuric acid solutions which necessitated evaporation to dryness.

Experiment 1. Determination of lead in a test solution containing 70.3 $\mu \mathrm{g}$ of lead, no sulfuric acid and without evaporation of solutions.-A preliminary calculation, made after the visual color change, indicated that the lead exceeded $55 \mu \mathrm{g}$. Consequently, this amount was added to the comparison, or "known solution," before using the photronic cell. The first determination with the photronic cell showed this amount to be too small, as was expected. The next amount of lead, $11.8 \mu \mathrm{g}$, was still not enough and $11.3 \mu \mathrm{g}$ more were added. The measurements with the photronic cell at this point showed that the total amount of lead in the known solution exceeded that in the test solution. The equivalence point having been passed, all the data needed to calculate the final result were available. The details of procedure are given below, followed by the calculations in table 1 . 


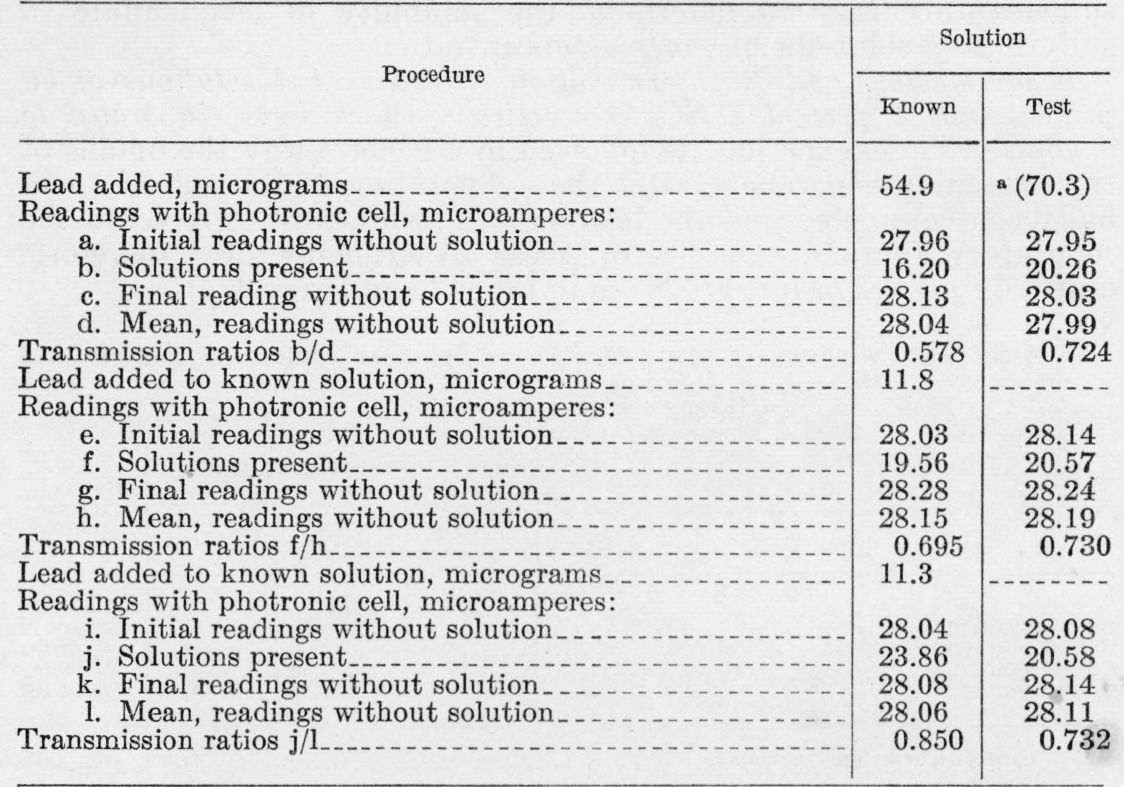

* This amount was unknown to the analyst.

Considering the transmission ratios, we have the results in table 1. TABLE 1.-Determination of lead added to a test solution containing no sulfuric acid [Evaporation to dryness not required]

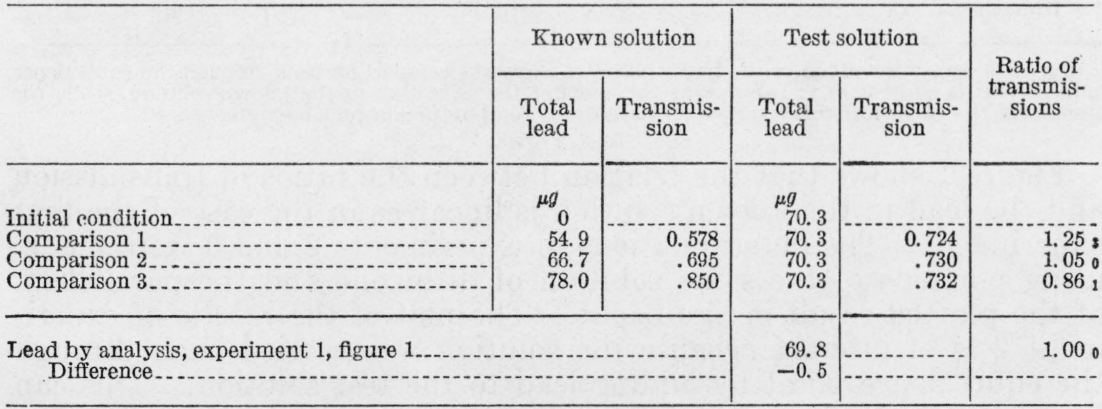

The transmission ratios in the last column of table 1 were plotted (fig. 1) against the amounts of lead in the known solution. The relationship is evidently linear within a limited range. The equivalence point is shown by the intersection at a ratio of unity. The amount of lead corresponding to this unit ratio is $69.8 \mu \mathrm{g}$, which agrees with the amount in the test solution to within $0.5 \mu \mathrm{g}$, or 0.7 percent. It is possible to go back and forth over the equivalence point.

Similar tests, described below, were made on known amounts of lead in strong and also in dilute solutions of sulfuric acid which were carried through the evaporation process. By numerous checks of this kind we satisfied ourselves that the method can be used with 
sufficient accuracy to determine the solubility of lead sulfate in sulfuric acid solutions of varying concentration.

Experiments 2 and 3. Determination of lead in test solutions of 50 percent and 2 percent $\mathrm{H}_{2} \mathrm{SO}_{4}$, respectively, which were evaporated to dryness. - These experiments followed in a general way the details of the preceding experiment after the evaporation of the sulfuric acid had been completed and the lead sulfate residues transferred to the separatory funnels. Details of these experiments are, therefore, omitted, but the results are given in table 2 and figure 1.

TABLE 2.-Determination of lead added to test solutions containing sulfuric acid

[Evaporation to dryness required]

\begin{tabular}{|c|c|c|c|c|}
\hline & \multirow{2}{*}{$\begin{array}{l}\text { Total lead } \\
\text { in known } \\
\text { solution }\end{array}$} & \multicolumn{2}{|c|}{ Test solution } & \multirow{2}{*}{$\begin{array}{l}\text { Ratio of } \\
\text { transmis- } \\
\text { sions }\end{array}$} \\
\hline & & $\mathrm{H}_{2} \mathrm{SO}_{4}$ & Total lead & \\
\hline $\begin{array}{l}\text { Initial condition } \\
\text { Comparison 1 } \\
\text { Comparison 2 } \\
\text { Comparison } 3\end{array}$ & $\begin{array}{r}\mu g \\
\quad 0 \\
40.4 \\
46.8 \\
146.8\end{array}$ & $\begin{array}{r}\text { Percent } \\
50 \\
0 \\
0 \\
0\end{array}$ & \begin{tabular}{r|}
$\mu g$ \\
44.5 \\
44.5 \\
44.5 \\
152.3
\end{tabular} & $\begin{array}{l}1.043 \\
0.967 \\
1.063\end{array}$ \\
\hline $\begin{array}{l}\text { Lead by analysis, experiment 2, figure } 1 \\
\text { Difference... }\end{array}$ & & & $\begin{array}{r}44.0 \\
-0.5\end{array}$ & $1.00_{0}$ \\
\hline $\begin{array}{l}\text { Initial condition } \\
\text { Comparison } 1 \text { - } \\
\text { Comparison } 2 \\
\text { Comparison } 32 \\
\text { Comparison } 4\end{array}$ & $\begin{array}{l}0 \\
41.2 \\
41.2 \\
49.8 \\
49.8\end{array}$ & $\begin{array}{l}2 \\
0 \\
0 \\
0 \\
0\end{array}$ & $\begin{array}{l}40.3 \\
40.3 \\
40.3 \\
40.3 \\
40.3\end{array}$ & $\begin{array}{l}0.99_{8} \\
1.002 \\
0.89_{2} \\
0.89_{4}\end{array}$ \\
\hline $\begin{array}{l}\text { Lead by analysis, experiment } 3 \text {, figure } 1 \ldots \\
\text { Difference... }\end{array}$ & & & $\begin{array}{r}41.2 \\
+0.9\end{array}$ & $1.00_{0}$ \\
\hline
\end{tabular}

$17.8 \mu \mathrm{g}$ of lead were added to the test solution to carry the comparison back through the equivalence point. This is equivalent to subtracting this amount from the lead in the known solution, while the amount in the test solution is regarded for purposes of computation as remaining unchanged.

Figure 1 shows that the relation between the ratios of transmission and the lead in the known solution is linear as in the case of the first experiment. The determinations of experiments 2 and 3 were made, using portions of the same solution of dithizone and the parallelism of the plotted result is significant. The plot of the results of experiment 2 is of interest because the solution was carried back through the equivalence point by adding lead to the test solution. This can be done provided enough dithizone is present in each funnel. The results of all comparisons fall on the same straight line. The small figures indicate the numerical order of the comparisons. Although it is difficult to distinguish more than two points on the line, for experiment 3 there are actually four comparisons, as shown in table 2.

The small changes in repeated determinations of the transmission of the test solution, as shown in table 1, always progress in the same direction. This has been observed repeatedly. These changes are probably not accidental variations, but indicate a slow oxidation of the dithizone. We believe that this explanation is more probable than that given by Clifford and Wichmann [3, page 140] who studied the equilibrium conditions and concluded that lead is continuously 
drawn from the organic phase merely by prolonged shaking of the solutions. This and other points relating to the $\mathrm{pH}$ of the solutions deserve further consideration and test in establishing a method for determining lead. They did not, however, seem to justify further time and effort in the present work as our problem was primarily to determine the solubility of lead sulfate. The results of tests on solutions to which known amounts of lead were added showed that our method was amply accurate for the purpose.

Any error that arises from oxidation of the dithizone was minimized in our experiments by taking the successive ratios of transmis-

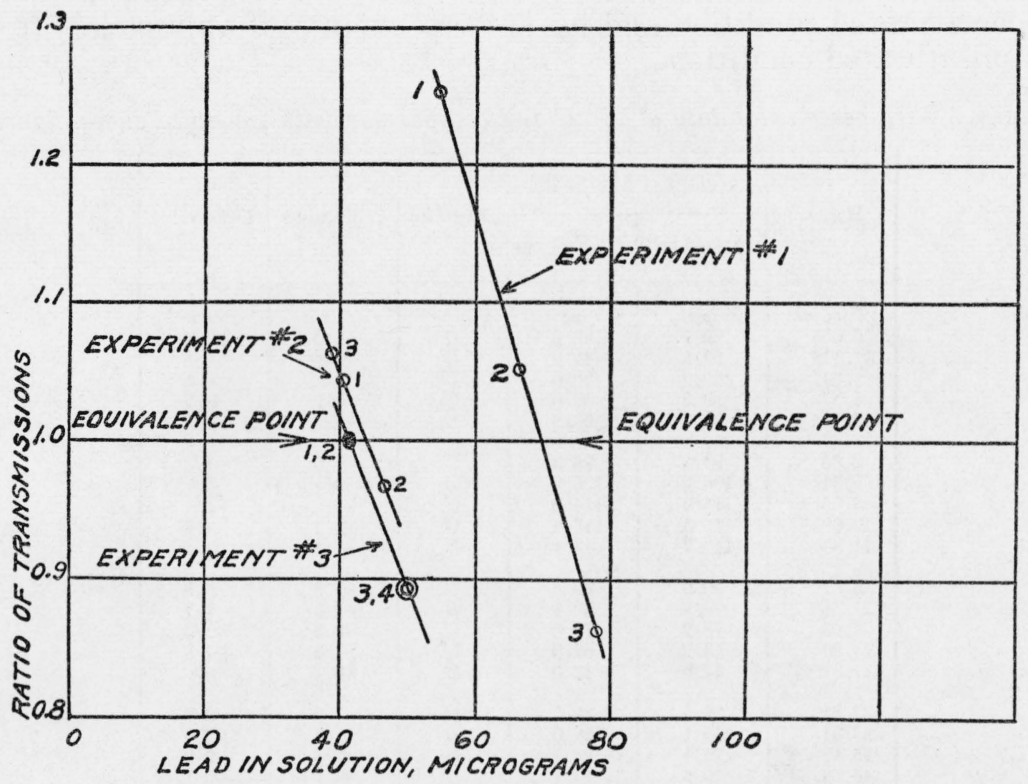

FIGURE 1.-Relation of transmission ratios to the amounts of lead in solution.

sion. Likewise, any error which would result from an unknown distribution of the lead between the aqueous and organic phases is nullified by the comparison of known and unknown solutions carried through exactly the same processes.

The desirability, however, of extending the work to study the use of green filters or both red and green filters is recognized. For some lead concentrations one may be better than the other. If both are used, two different curves could be obtained, and the equivalence point calculated from one should check the determination from the other.

We made two determinations of the $\mathrm{pH}$ of the aqueous phase, using a glass electrode, and obtained the value 9.4 , which is within the range recommended by Clifford and Wichmann.

\section{DETERMINATION OF SULFURIC ACID}

The method for determining $\mathrm{H}_{2} \mathrm{SO}_{4}$ in the solutions was by densities at $25^{\circ}$, as described in detail in our paper entitled Chemical Reactions in the Lead Storage Battery [6], except in the more dilute solutions. In these the acid concentration was determined by titration. 


\section{EXPERIMENTAL RESULTS}

The amount of lead in $25 \mathrm{ml}$ of each solution, saturated at $25^{\circ} \mathrm{C}$, was determined and the experimental data are given in table 3 as observed values, together with the acid concentration of the respective solutions expressed as the percentage of $\mathrm{H}_{2} \mathrm{SO}_{4}$. Columns 3,5 , and 6 of this table need not be considered now. They relate to smoothed curves, shown in figure 2 , which are discussed on page 65 . Corresponding data are given in table 4 for determinations made at $0^{\circ} \mathrm{C}$. The direction from which saturation equilibrium was approached is indicated in these tables by $D$ ("down" points) if approached from a supersaturated condition and by $U$ ("up" points) if approached from an unsaturated condition.

TABLE 3.-Experimental data at $25^{\circ} \mathrm{C}$ and comparison with smoothed curve, figure 2

\begin{tabular}{|c|c|c|c|c|c|}
\hline \multirow{2}{*}{$\mathrm{H}_{2} \mathrm{SO}_{4}$} & \multicolumn{2}{|c|}{ Weight, $\mathrm{Pb}$ in $25 \mathrm{ml}$} & \multirow{2}{*}{ Direction } & \multirow{2}{*}{ Difference } & \multirow{2}{*}{ Difference } \\
\hline & Observed & From curve & & & \\
\hline $\begin{array}{c}\text { Percent } \\
0.086 \\
.118 \\
.647 \\
1.57 \\
2.28\end{array}$ & $\begin{array}{c}\mu \boldsymbol{g} \\
89.7 \\
82.5 \\
80.0 \\
89.2 \\
93.7\end{array}$ & $\begin{array}{c}\mu g \\
88.3 \\
82.9 \\
80.0 \\
89.0 \\
93.5\end{array}$ & $\begin{array}{l}D \\
U \\
U \\
U \\
D\end{array}$ & $\begin{array}{c}\mu g \\
+1.4 \\
-0.4 \\
0 \\
+.2 \\
+.2\end{array}$ & $\begin{array}{c}\text { Percent } \\
+1.6 \\
-0.5 \\
0 \\
+.2 \\
+.2\end{array}$ \\
\hline $\begin{array}{r}2.60 \\
5.31 \\
9.65 \\
10.09 \\
11.80\end{array}$ & $\begin{array}{r}94.3 \\
106.2 \\
114.0 \\
115.5 \\
112.7\end{array}$ & $\begin{array}{r}95.3 \\
106.2 \\
114.0 \\
115.4 \\
113.1\end{array}$ & $\begin{array}{l}U \\
U \\
U \\
U \\
D\end{array}$ & $\begin{array}{c}-1.0 \\
0 \\
0 \\
+.1 \\
-.4\end{array}$ & $\begin{array}{c}-1.0 \\
0 \\
0 \\
+.1 \\
-.4\end{array}$ \\
\hline $\begin{array}{l}19.87 \\
21.58 \\
21.93 \\
24.90 \\
31.87\end{array}$ & $\begin{array}{l}90.0 \\
79.4 \\
78.2 \\
68.2 \\
42.0\end{array}$ & $\begin{array}{l}89.5 \\
80.7 \\
79.0 \\
67.0 \\
42.0\end{array}$ & $\begin{array}{l}U \\
D \\
U \\
U \\
U\end{array}$ & $\begin{array}{c}+.5 \\
-1.3 \\
-0.8 \\
+1.2 \\
0\end{array}$ & $\begin{array}{c}+.6 \\
-1.7 \\
-1.0 \\
+1.8 \\
0\end{array}$ \\
\hline $\begin{array}{l}32.51 \\
33.31 \\
45.48 \\
48.58\end{array}$ & $\begin{array}{l}38.5 \\
39.1 \\
20.1 \\
19.5\end{array}$ & $\begin{array}{l}39.7 \\
38.0 \\
20.7 \\
19.1\end{array}$ & \begin{tabular}{|l|}
$U$ \\
$D$ \\
$D$ \\
$U$
\end{tabular} & $\begin{array}{r}-1.2 \\
+1.1 \\
-0.6 \\
+.4 \\
\end{array}$ & $\begin{array}{r}-3.0 \\
+2.9 \\
-2.9 \\
+2.1 \\
\end{array}$ \\
\hline \multicolumn{4}{|c|}{ A verage of all determinations. } & \pm 0.6 & \pm 1.0 \\
\hline
\end{tabular}

TABLE 4.-Experimental data at $0^{\circ} \mathrm{C}$ and comparison with smoothed curve, figure 2

\begin{tabular}{|c|c|c|c|c|c|}
\hline \multirow{2}{*}{$\mathrm{H}_{2} \mathrm{SO}_{4}$} & \multicolumn{2}{|c|}{ Weight, $\mathrm{Pb}$ in $25 \mathrm{ml}$} & \multirow{2}{*}{ Direction } & \multirow{2}{*}{ Difference } & \multirow{2}{*}{ Difference } \\
\hline & Observed & From curve & & & \\
\hline $\begin{array}{c}\text { Percent } \\
0.053 \\
.065 \\
.280 \\
.462 \\
1.13\end{array}$ & $\begin{array}{c}\mu g \\
45.8 \\
45.7 \\
35.2 \\
35.0 \\
36.3\end{array}$ & $\begin{array}{c}\mu g \\
47.1 \\
44.5 \\
35.4 \\
35.1 \\
36.0\end{array}$ & $\begin{array}{l}D \\
U \\
D \\
U \\
D\end{array}$ & $\begin{array}{r}\mu g \\
-1.3 \\
+1.2 \\
-0.2 \\
-.1 \\
+.3\end{array}$ & $\begin{array}{c}\text { Percent } \\
-2.8 \\
+2.7 \\
-.6 \\
-.3 \\
+.8\end{array}$ \\
\hline $\begin{array}{r}4.70 \\
7.46 \\
8.93 \\
10.09 \\
17.49\end{array}$ & $\begin{array}{l}40.2 \\
48.3 \\
46.2 \\
49.4 \\
41.1\end{array}$ & $\begin{array}{l}41.5 \\
46.7 \\
48.5 \\
49.0 \\
41.8\end{array}$ & $\begin{array}{l}U \\
D \\
U \\
D \\
U\end{array}$ & $\begin{array}{r}-1.3 \\
+1.6 \\
+2.3 \\
+0.4 \\
-.7\end{array}$ & $\begin{array}{r}-3.1 \\
+3.4 \\
+4.7 \\
+.8 \\
-1.7\end{array}$ \\
\hline $\begin{array}{l}19.87 \\
37.58 \\
38.95\end{array}$ & $\begin{array}{r}38.7 \\
8.2 \\
11.6\end{array}$ & $\begin{array}{l}38.5 \\
11.3 \\
10.2\end{array}$ & $\begin{array}{l}D \\
D \\
U\end{array}$ & $\begin{array}{r}+.2 \\
-3.1 \\
+1.4\end{array}$ & $\begin{array}{r}+.5 \\
-27.4 \\
+13.7\end{array}$ \\
\hline $\begin{array}{l}\text { A verage } \\
\text { A verag }\end{array}$ & $\begin{array}{l}11 \text { determ } \\
\text { to } 20 \text {-perce }\end{array}$ & tions...- & & $\begin{array}{r} \pm 1.1 \\
\pm .0 .9\end{array}$ & $\begin{array}{l} \pm 4.8 \\
\pm 2.0\end{array}$ \\
\hline
\end{tabular}




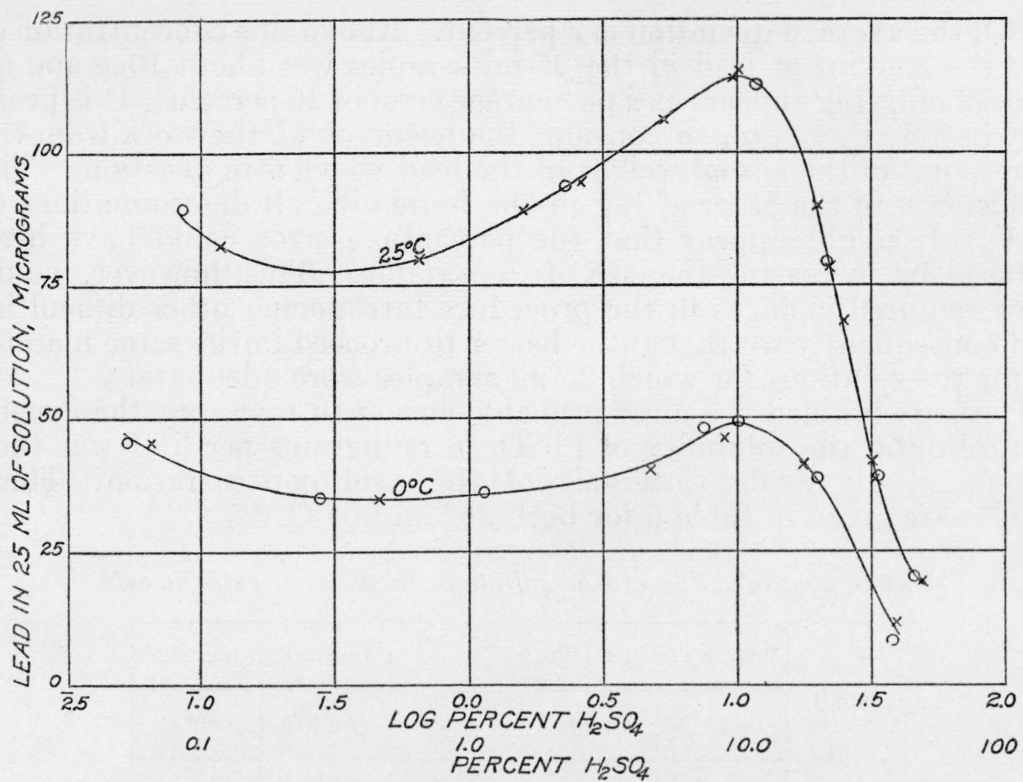

Figure 2.-Solubility of lead sulfate in sulfuric acid solutions.

Circles represent equilibrium values approached from supersaturated solutions and crosses from undersaturated solutions.

\section{SOLUBILITY OF LEAD SULFATE AT REGULAR INTERVALS OF SULFURIC ACID CONCENTRATION}

Since the experimental determinations reported in tables 3 and 4 were made at acid concentrations which have no simple relation to each other, all of the data were plotted and the solubility read from the curves at regular intervals. To avoid errors which might result from drawing a single curve, three separate plots on large scales were made, using the percentage of the acid concentrations, the square root of the percentage, and the logarithm of the percentage as abscissas. The average solubilities were then calculated from the readings made of these three plots, except below 1 percent, where the rectangular plot was not serviceable.

The average solubilities were plotted against the logarithms of the respective concentrations to obtain the curves shown in figure 2 . The individual points which were plotted for the purpose of drawing the curves are not shown in the figure, but the actual experimental determinations are plotted to show their deviations from the smoothed curve. These deviations afford a means of estimating the priecision of individual determinations. For each point the deviataon in micrograms from the smoothed curve of figure 2 has been read and tabulated in tables 3 and 4 . The average deviations are less than $1 \mu \mathrm{g}$ in the case of the determinations at $25^{\circ} \mathrm{C}$ and slightly more than $1 \mu \mathrm{g}$ for the determinations at $0^{\circ} \mathrm{C}$. The average percentage deviations are about 1 percent at the higher temperature, but at the lower temperature, they are, as might be expected, considerably more. This is because the total amount of lead sulfate in solutions at $0^{\circ} \mathrm{C}$ is very small. $\mathrm{If}_{\vec{b}}$ we consider only the solutions of less than 20 percent 
$\mathrm{H}_{2} \mathrm{SO}_{4}$ the average deviation is 2 percent. Above this concentration of acid the amount of lead in the $25-\mathrm{ml}$ samples was about $10 \mu \mathrm{g}$ and an error of only $1 \mu \mathrm{g}$ appears as a percentage error of 10 percent. It is probably better, therefore, to consider the accuracy of the work from the standpoint of the actual weight of the lead which is in question. The precision is of the order of $1 \mu \mathrm{g}$ in the more difficult determinations at $0^{\circ} \mathrm{C}$. It might appear that the percentage error could have been reduced by increasing the size of the sample. This, however, would have required changes in the procedure introducing other difficulties and consequently we thought it better to proceed in the same manner as for the solutions for which $25-\mathrm{ml}$ samples were adequate.

Having obtained the most probable curves to represent the experimental data, the solubility of $\mathrm{PbSO}_{4}$ in milligrams per liter was then calculated at regular intervals of the acid concentration. These results are given in table 5 for both $25^{\circ}$ and $0^{\circ} \mathrm{C}$.

TABLE 5.-Solubility of lead sulfate in solutions of sulfuric acid

\begin{tabular}{|c|c|c|c|c|c|}
\hline \multirow{2}{*}{$\mathrm{H}_{4} \mathrm{SO}_{4}$} & \multicolumn{2}{|c|}{ Weight, $\mathrm{PbSO}_{4}$ in a liter } & \multirow{2}{*}{$\mathrm{H}_{2} \mathrm{SO}_{4}$} & \multicolumn{2}{|c|}{ Weight, $\mathrm{PbSO}_{4}$ in a liter } \\
\hline & $t=25^{\circ} \mathrm{C}$ & $t=0^{\circ} \mathrm{C}$ & & $t=25^{\circ} \mathrm{C}$ & $t=0^{\circ} \mathrm{C}$ \\
\hline $\begin{array}{c}\text { Percent } \\
0.1 \\
.2 \\
.3 \\
.4 \\
.5\end{array}$ & $\begin{array}{c}m g \\
4.99 \\
4.61 \\
4.55 \\
4.57 \\
4.60\end{array}$ & $\begin{array}{l}m g \\
2.37 \\
2.13 \\
2.07 \\
2.05 \\
2.06\end{array}$ & $\begin{array}{c}\text { Percent } \\
6.0 \\
7.0 \\
8.0 \\
9.0 \\
10.0\end{array}$ & $\begin{array}{l}m g \\
6.33 \\
6.47 \\
6.57 \\
6.64 \\
6.68\end{array}$ & $\begin{array}{c}m g \\
2.58 \\
2.69 \\
2.79 \\
2.84 \\
2.86\end{array}$ \\
\hline $\begin{array}{r}.6 \\
.7 \\
.8 \\
.9 \\
1.0\end{array}$ & $\begin{array}{l}4.65 \\
4.71 \\
4.77 \\
4.84 \\
4.91\end{array}$ & $\begin{array}{l}2.06 \\
2.07 \\
2.07 \\
2.08 \\
2.10\end{array}$ & $\begin{array}{l}15.0 \\
20.0 \\
25.0 \\
30.0 \\
35.0\end{array}$ & $\begin{array}{l}6.28 \\
5.18 \\
3.87 \\
2.82 \\
2.02\end{array}$ & $\begin{array}{l}2.63 \\
2.21 \\
1.76 \\
1.27 \\
0.84\end{array}$ \\
\hline $\begin{array}{l}2.0 \\
3.0 \\
4.0 \\
5.0\end{array}$ & $\begin{array}{l}5.37 \\
5.70 \\
5.95 \\
6.15\end{array}$ & $\begin{array}{l}2.18 \\
2.27 \\
2.36 \\
2.46\end{array}$ & $\begin{array}{l}40.0 \\
45.0 \\
50.0\end{array}$ & $\begin{array}{l}1.52 \\
1.23 \\
1.08\end{array}$ & $\begin{array}{c}.53 \\
-5 \\
\end{array}$ \\
\hline
\end{tabular}

\section{DISCUSSION OF RESULTS}

The data given in table 5 and in figure 2 show definite maxima and minima for the solubility. Each curve for a specified temperature shows that three different solutions with the same lead content are possible. At each temperature the curve passes through a maximum at about 10 percent acid and a minimum at about 0.3 percent acid.

It is interesting to compare these results with those published by us [7] 2 years ago for mercurous sulfate in corresponding concentrations of sulfuric acid. In order to compare the solubility curves of lead sulfate and mercurous sulfate and to show the remarkable similarity in their characteristics, we have computed the lead sulfate results to the same basis of acid concentration as was used in the former paper. In figure 3 the results for both salts are plotted, but it should be noted that mercurous sulfate is given as the ordinate instead of mercury as in the earlier paper. The similarity of the curves is at once apparent.

If correction is made in the case of the mercurous sulfate for the total molar concentration in the dilute solutions, since mercurous sulfate is sufficiently soluble to affect the properties of the solution, the dotted portion of the upper curve is obtained. 
We may now compare the solubility of mercurous sulfate and lead sulfate in solutions of corresponding strength. The results are given in table 6. The ratio of mercurous sulfate at $28^{\circ} \mathrm{C}$ to lead sulfate at $25^{\circ} \mathrm{C}$ is surprisingly constant over a very wide range of acid concen-

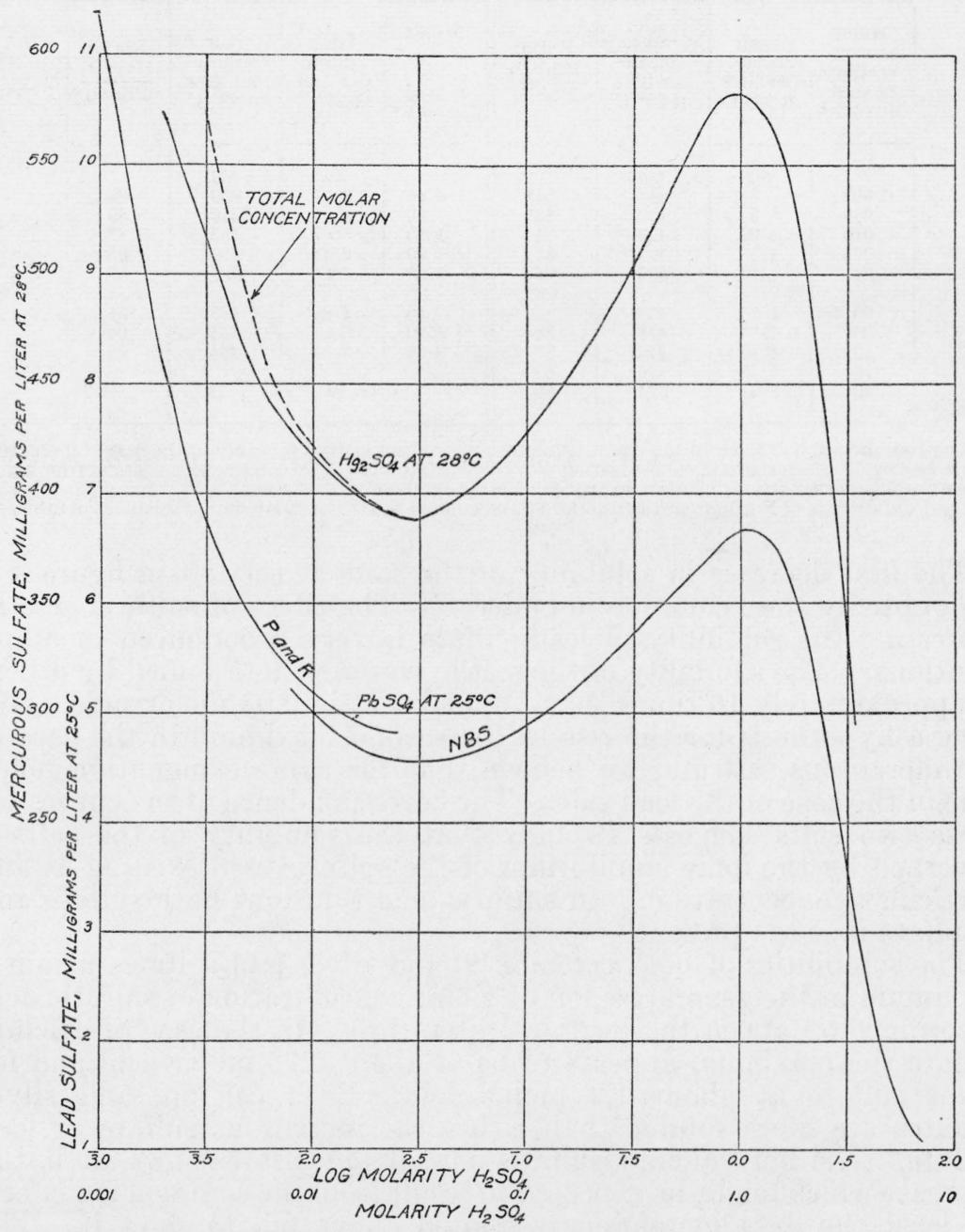

FIGURE 3.-Comparison of solubility curves of lead and mercurous sulfates in solutions of sulfuric acid.

The curve marked " $P$ and $R$ " represents data of Purdum and Rutherford [8] calculated to $25^{\circ} \mathrm{C}$. The dotted portion of the $\mathrm{Hg}_{2} \mathrm{SO}_{4}$ curve represents the total concentration of $\mathrm{H}_{2} \mathrm{SO}_{4}$ plus $\mathrm{Hg}_{2} \mathrm{SO}_{4}$.

trations. From 3.5 molar to 0.0025 molar, more than a 1000:1 change in the acid concentration, the ratio of solubilities is nearly constant. The average deviation of a single comparison from the mean value, 88 , is about 2. This is comparable with the experimental error estimated for the two series of measurements. Above 2 molar acid the ratios differ slightly more, but it should be noted that in such cases the 
amounts of lead and mercurous sulfate are relatively small and percentage errors naturally become larger. ${ }^{3}$

TABLE 6.-Comparison of the solubilities of lead and mercurous sulfates

\begin{tabular}{|c|c|c|c|c|c|c|c|}
\hline $\begin{array}{l}\text { Molar } \\
\text { concen- } \\
\text { tration } \\
\text { of acid } \\
\text { plus salt }\end{array}$ & $\begin{array}{c}\text { Lead } \\
\text { sulfate } \\
\text { per liter } \\
\text { at } 25^{\circ} \mathrm{C}\end{array}$ & $\begin{array}{c}\text { Mercurous } \\
\text { sulfate } \\
\text { per liter } \\
\text { at } 28^{\circ} \mathrm{C}\end{array}$ & $\begin{array}{l}\text { Ratio: } \\
\frac{\mathrm{Hg}_{2} \mathrm{SO}_{4}}{\mathrm{PbSO}_{4}}\end{array}$ & $\begin{array}{c}\text { Molar } \\
\text { concen- } \\
\text { tration } \\
\text { of acid } \\
\text { plus salt }\end{array}$ & $\begin{array}{c}\text { Lead } \\
\text { sulfate } \\
\text { per liter } \\
\text { at } 25^{\circ} \mathrm{C}\end{array}$ & $\begin{array}{c}\text { Mercurous } \\
\text { sulfate } \\
\text { per liter } \\
\text { at } 28^{\circ} \mathrm{C}\end{array}$ & $\begin{array}{l}\text { Ratio: } \\
\frac{\mathrm{Hg}_{2} \mathrm{SO}_{4}}{\mathrm{PbSO}_{4}}\end{array}$ \\
\hline $\begin{array}{l}0.002 . \\
.005 \\
.010 \\
.025 \\
.04\end{array}$ & $\begin{array}{l}m g \\
7.3 \\
5.9 \\
4.99 \\
4.58 \\
4.57\end{array}$ & $\begin{array}{l}m g \\
615 \\
490 \\
419 \\
390 \\
393\end{array}$ & $\begin{array}{l}84 b \\
83 b \\
84 \\
85 \\
86\end{array}$ & $\begin{array}{l}0.60 \\
.80 \\
1.00 \\
1.50 \\
2.00\end{array}$ & $\begin{array}{c}m g \\
6.27 \\
6.51 \\
6.67 \\
6.47 \\
5.81\end{array}$ & $\begin{array}{l}m g \\
559 \\
579 \\
583 \\
560 \\
507\end{array}$ & $\begin{array}{l}89 \\
89 \\
87 \\
87 \\
87\end{array}$ \\
\hline $\begin{array}{l}.06 \\
.08 \\
.10\end{array}$ & $\begin{array}{l}4.65 \\
4.77 \\
4.89\end{array}$ & $\begin{array}{l}405 \\
418 \\
426\end{array}$ & $\begin{array}{l}87 \\
88 \\
87\end{array}$ & $\begin{array}{l}2.50 \\
3.00 \\
3.50\end{array}$ & $\begin{array}{l}4.80 \\
3.87 \\
3.07\end{array}$ & $\begin{array}{l}439 \\
364 \\
295\end{array}$ & $\begin{array}{l}91 \\
94 \\
96\end{array}$ \\
\hline .40 & 5.91 & 524 & 89 & \multicolumn{3}{|c|}{ Average................. } & 88 \\
\hline
\end{tabular}

- The concentration of the solution has been corrected for the dissolved salt only in the case of mercurous sulfate (see fig. 2) when the acid concentration was below 0.03 molar. No correction is necessary for higher concentrations nor for the lead sulfate in any concentration given in the table.

Lead sulfate data of Purdum and Rutherford [8] calculated to $25^{\circ} \mathrm{C}$. NBS data, remainder of table.

The first decrease in solubility of the salts at the left in figure 3 is undoubtedly the "common ion effect." The effect of sulfuric acid in repressing the solubility of lead sulfate is very pronounced in dilute solutions. The solubility of the salt in water as determined by others is approximately 10 times that found by us in 0.03 molar acid. We gave a hypothesis for the rise to the second maximum in the case of the mercurous salt and we believe that the same explanation holds true in the case of the lead salt. The correspondence of the curves for these two salts suggests strongly that the solubility of the salts is governed by the ionic equilibrium of the sulfuric acid existing at any particular concentration. In sulfuric acid solutions both sulfate and bisulfate ions are present.

The solubilities of both calcium [9] and silver [10] sulfates attain a maximum in the general region of molar concentration of sulfuric acid according to data in the technical literature. In the case of calcium sulfate the maximum appears to be at about 0.76 molar acid and for silver sulfate at about 1.2 molar acid. Both calcium and silver sulfates are more soluble than either the mercurous sulfate or lead sulfate. Neither calcium sulfate nor silver sulfate shows an initial decrease which might be expected to result from the common ion effect. At least the data in references quoted above fail to show it. The reason for not finding an initial decrease in solubility of these salts is evident if the data are plotted against total molar concentrations, as we have done in the case of mercurous sulfate, figure 3. The lowest total concentrations are in the region of or above that at which we observed the minimum solubility of lead and mercurous sulfates.

8 A comparison might be made on the basis of corresponding ionic strength of the solutions. Such a comparison, however, would differ little from that given in table 6 and would affect principally the comparison of solubilities in the two most dilute solutions shown in the table. Further comparisons of still more dilute solutions cannot be made because of hydrolysis of the mercurous sulfate. 


\section{COMPARISON WITH THE RESULTS OF OTHERS}

Various determinations of the solubility of lead sulfate in water and in solutions of sulfuric acid have appeared in the technical literature. Several of these are mentioned in Dolezalek's book [11] and in the papers by Purdum and Rutherford [8], by Crockford and Brawley [12], and Huybrechts and Ramelot [13]. Data are given also by Seidell [14] and by Mellor [15]. We have made use of the data of Purdum and Rutherford in table 6 to supply values in the range of low acid concentrations which our work does not cover. Their determinations overlap ours in the region of 0.1 to 0.25 percent sulfuric acid. A comparison of their results with ours is given in table 7. Since their results were given at $20^{\circ} \mathrm{C}$, we have converted them to $25^{\circ} \mathrm{C}$ by applying linear corrections based on our observations at 0 and $25^{\circ} \mathrm{C}$. Such a procedure cannot be justified for large temperature differences. The comparison of our results with those of Purdum and Rutherford, which were obtained by an entirely different method, then shows very close agreement.

TABLE 7.-Comparison of results with those of Purdum and Rutherford

\begin{tabular}{|c|c|c|c|c|}
\hline \multicolumn{2}{|c|}{ Concentration $\mathrm{H}_{2} \mathrm{SO}_{4}$} & \multicolumn{2}{|c|}{ Lead sulfate per liter } & \multirow[b]{2}{*}{ Difference } \\
\hline $\begin{array}{l}\text { Equivalent } \\
\text { per liter }\end{array}$ & Percent & $\begin{array}{l}\text { Purdum and } \\
\text { Rutherford, } \\
\text { calculated } \\
\text { to } 25^{\circ} \mathrm{C}\end{array}$ & $\begin{array}{l}\text { NBS, ob- } \\
\text { served at } \\
25^{\circ} \mathrm{C}\end{array}$ & \\
\hline $\begin{array}{r}0.02 \\
.05\end{array}$ & $\begin{array}{r}0.098 \\
.245\end{array}$ & $\begin{array}{l}m g \\
5.2 \\
4.8\end{array}$ & $\begin{array}{l}m g \\
5.0 \\
4.6\end{array}$ & $\begin{array}{r}m g \\
0.2 \\
.2\end{array}$ \\
\hline
\end{tabular}

Comparison of our results with those of Crockford and Brawley is difficult because the actual determinations made by them are not reported in their paper, and the number of their determinations is not known. Their data, which were evidently read from a smoothed curve, fail to show any indication of a maximum solubility, which we observed in molar acid. Although they estimate their results to be accurate to 0.2 part per million of solution in this range, there is a large discrepancy between their results and ours, which are threefold greater than theirs at this point. We feel very confident that this maximum exists. We found it at both $25^{\circ}$ and $0^{\circ} \mathrm{C}$. It is entirely analogous to the results for mercurous sulfate, and the accuracy of our individual determinations, as shown by table 3 , is amply sufficient to establish it. At the higher concentrations of acid reported in this paper better agreement with their data was found.

Huybrechts and Ramelot made determinations of the solubility of lead sulfate in sulfuric acid solutions up to 10 percent. In general, our values at $25^{\circ} \mathrm{C}$ are in good agreement with theirs and almost uniformly lie between their values at $18^{\circ}$ and $30^{\circ} \mathrm{C}$. 


\section{REFERENCES}

[1] H. Fischer, Z. anorg. Chem. 42, 1025 (1929).

[2] H. Fischer, Z. anorg. Chem. $4 \%, 685$ (1934).

[3] P. A. Clifford and H. J. Wichmann, J. Assn. Official Agr. Chem. 19, 130 (1936).

[4] Ind. Eng. Chem. 1\%, 756 (1925).

[5] See [1 and 2], also [3, p. 131].

[6] G. W. Vinal and D. N. Craig, J. Research NBS 14, 456 (1935) RP778.

[7] D. N. Craig, G. W. Vinal, and F. E. Vinal, J. Research NBS 1\%, 709 (1936) RP939.

[8] Purdum and Rutherford, J. Am. Chem. Soc. 55, 3221 (1933).

[9] F. K. Cameron and J. F. Breazeale, J. Phys. Chem. y, 574 (1903).

[10] G. Àkerlöf and H. C. Thomas, J. Am. Chem. Soc. 56, 597 (1934).

[11] F. Dolezalek, Theory of the Lead Accumulator, p. 144 (1904).

[12] H. D. Crockford and D. J. Brawley, J. Am. Chem. Soc. 56, 2600 (1934).

[13] M. Huybrechts and H. Ramelot, Bul. soc. chim. Belg. 36, 239 (1927).

[14] A. Seidell, Solubilities of Inorganic and Organic Compounds.

[15] J. W. Mellor, Comprehensive treatise on inorganic and theoretical chemistry \%, 803 (1927).

Washington, August 8, 1938. 